\title{
Comparison of Methods for Protoplast Formation in Bacillus thuringiensis
}

\author{
By KEVIN B. TEMEYER \\ US Livestock Insects Laboratory, Agricultural Research Service, US Department of Agriculture, \\ PO Box 232, Kerrville, TX 78029, USA
}

(Received 8 July 1986; revised 4 November 1986)

In preparation of Bacillus thuringiensis protoplasts or cell-free lysates, hydrolysis of cell walls was due to endogenous autolytic activity and was largely independent of lysozyme. Purified cell walls of $B$. thuringiensis were resistant to lysozyme, lysostaphin, chitinase, trypsin and Bacillus subtilis proteinase, but were hydrolysed by $B$. thuringiensis autolytic enzymes or an $N$-acetylmuramidase (mutanolysin) from Streptomyces globisporus. Mutanolysin was effective in preparation of protoplasts or lysates of $B$. thuringiensis, and, unlike lysozyme, did not interfere with electrophoretic analysis of DNA.

\section{INTRODUCTION}

Bacillus thuringiensis has been of increasing interest because it produces insecticidal toxins during growth and sporulation, but physiological and genetic studies are hampered by lack of efficient and versatile techniques for genetic manipulation in this organism (Martin \& Dean, $1980 \mathrm{~b}$ ). Although transformation of $B$. thuringiensis protoplasts has been reported (Azizbekyan et al., 1982; Martin \& Dean, 1980 a; Miteva et al., 1981), the efficiency of transformation was very low, possibly due to incomplete removal of the cell walls by lysozyme (Alikhanian et al., 1981; Martin et al., 1981). Many researchers have alluded to difficulties in the use of lysozyme for hydrolysis of $B$. thuringiensis cell walls (Miteva et al., 1981; Gonzalez \& Carlton, 1982; Kingan \& Ensign, 1968 ; Lereclus et al., 1982). Martin et al. (1981) reported that growth of $B$. thuringiensis in L-broth without glucose resulted in greater lysozyme sensitivity than growth in Lbroth with glucose. High concentrations of lysozyme have also been used in an effort to obtain efficient cell wall hydrolysis; however, excess lysozyme may lead to undesirable effects such as interference with cell wall regeneration due to strong binding of lysozyme to the protoplast membrane (Harrington \& Baddiley, 1983) or proteolytic activity associated with lysozyme in extracts (Oliver \& Stadtman, 1983). Experiments were initiated in this laboratory to modify existing methods, or to develop new methods for preparation of $B$. thuringiensis protoplasts.

\section{METHODS}

Bacterial strains. B. thuringiensis strains K Bt4 (var. kurstaki, a derivative of HD-1) and HD522 (var. israelensis) were used throughout this study. Cultures were routinely grown in L-broth as described previously (Temeyer, 1984).

Preparation of crude autolytic enzyme. The procedure of Kingan \& Ensign ( $1968 b$ ) was modified by growth of the cells to late exponential phase in tryptic soy broth (Difco) containing $0.1 \%$ yeast extract, followed by synchronous sporulation in mineral salts medium (DCE) without glutamate (Temeyer, 1984). Sporulated cultures were collected by centrifugation when $1 \%$ of the spores had been released from the sporangia. The pellet was resuspended in $1 / 25$ culture volume of $20 \mathrm{~mm}$-potassium phosphate, $\mathrm{pH} 8.0$, containing $\mathrm{MgCl}_{2}, \mathrm{MnCl}_{2}$ and $\mathrm{CaCl}_{2}$ (each $1 \mathrm{~mm}$ ), plus $0 \cdot 1 \mathrm{~mm}-\mathrm{CoCl}_{2}$. Toluene was added to $2.5 \%(\mathrm{v} / \mathrm{v})$ after $2 \mathrm{~h}$ at $28^{\circ} \mathrm{C}$ with shaking, and the loosely capped slurry was allowed to stand at $22^{\circ} \mathrm{C}$ overnight. The autolysate was centrifuged, rinsed with a minimal volume of distilled water, and the supernatants were pooled. One-tenth volume $1 \mathrm{M}$-potassium phosphate, $\mathrm{pH} 7 \cdot 5$, was added and the crude autolysate was fractionated by precipitation with solid ammonium sulphate at constant $\mathrm{pH}$ while stirring at $0{ }^{\circ} \mathrm{C}$. Material which precipitated at 30-70\% saturation (Di Jeso, 1968) was dialysed against $10 \mathrm{~mm}-\mathrm{Tris} / \mathrm{HCl}$, $\mathrm{pH} 8 \cdot 0$, freeze-dried, and stored in $50 \%(\mathrm{v} / \mathrm{v})$ glycerol at $-20^{\circ} \mathrm{C}$. Hydrolytic activity of the crude autolytic enzyme preparation was stable for at least one year. 
Preparation of $B$. thuringiensis cell walls. Purified cell walls were prepared from frozen, spore-free vegetative cells by sonication in distilled water until more than $99.9 \%$ of the cells had been broken as indicated by phase-contrast microscopy. The disrupted cell suspension was centrifuged $(23500 \mathrm{~g})$ to pellet particulate matter, resuspended in distilled water, and boiled for $30 \mathrm{~min}$ to inactivate lytic enzymes. The suspension was cooled to $37^{\circ} \mathrm{C}$ and incubated for $30 \mathrm{~min}$ with RNAase A and DNAase I (100 $\mu \mathrm{g} \mathrm{ml}^{-1}$ each) followed by $30 \mathrm{~min}$ with $100 \mu \mathrm{g}$ trypsin $\mathrm{ml}^{-1}$. The cell walls were collected, resuspended, and boiled for $1-5 \mathrm{~min}$ in $1 \%(\mathrm{w} / \mathrm{v})$ sodium dodecyl sulphate (SDS). Particulate matter was pelleted $(4800 \mathrm{~g})$ and rinsed a total of nine times, first with distilled water $(2 \times)$, then $1 \mathrm{M}-\mathrm{NaCl}(2 \times)$, followed by $1 \mathrm{mM}-\mathrm{Tris} / \mathrm{HCl}+1 \mathrm{mM}-\mathrm{Na}_{2}$ EDTA, $\mathrm{pH} 7.5(2 \times)$, and finally with distilled water $(3 \times)$. A concentrated suspension was freeze-dried, yielding a spongy white material. A water suspension of $1 \mathrm{mg} \mathrm{ml}^{-1}$ gave a Klett reading of 123 (blue, no. 42 filter).

Assay of lytic activity. A colorimetric assay of $B$. thuringiensis cell wall hydrolysis was used to compare relative activity of hydrolytic enzymes. Purified cell walls were dyed with Procion red MX5B as described by Forsberg \& Rogers (1971). Cell wall hydrolysis was accompanied by release of non-sedimentable dye. Dyed cell walls of $B$. thuringiensis were incubated with various lytic enzymes at $23^{\circ} \mathrm{C}$ with agitation. The suspensions were diluted and centrifuged at $5^{\circ} \mathrm{C}$ for $15-30 \mathrm{~min}(11000 \mathrm{~g})$ and relative hydrolysis was determined as absorbance of the supernatant at $530 \mathrm{~nm}$.

Electrophoretic analysis. Preparations of plasmid DNA (purified by isopycnic centrifugation) containing lysozyme, mutanolysin or autolytic enzyme were incubated at $37^{\circ} \mathrm{C}$ for $30 \mathrm{~min}$ to test for nuclease activity or the formation of intermolecular complexes interfering with electrophoretic analysis of DNA. The DNA samples were electrophoretically separated on $0.7 \%$ agarose gels in Tris/borate buffer ( $89 \mathrm{~mm}$-Trizma base, $89 \mathrm{~mm}$-boric acid, $2.5 \mathrm{mM}-\mathrm{Na}_{2}$ EDTA, pH 8.3), and visualized by fluorescence of the ethidium-bromide-stained gels under UV $(300 \mathrm{~nm})$ illumination.

Enzymes and chemicals. Streptomyces globisporus $\mathrm{N}$-acetylmuramidase (mutanolysin) was obtained from Sigma, or from Miles Laboratories. Bacillus subtilis proteinase and Serratia marcesens chitinase were obtained from US Biochemical Corp. Egg white lysozyme (grade I), lysostaphin, RNAase A, DNAase I, trypsin and D-cycloserine were obtained from Sigma. Procion red MX5B was kindly donated by Dr Richard Bryant of Imperial Chemical Industries. All other materials were of the highest grade available commercially.

\section{RESULTS AND DISCUSSION}

Lysozyme sensitivity of $B$. thuringiensis was monitored by measurement of the reduction in turbidity of the cell suspension, clarity of the suspension after addition of SDS to $2 \%$, release of plasmid DNA as monitored by electrophoresis in agarose gels, or conversion to spherical form (spheroplasts) in the presence of $0 \cdot 25 \mathrm{M}$-sucrose. Removal of the cell wall with lysozyme was highly dependent on the condition and treatment of the cells during growth and harvest. The presence of glucose during growth in L-broth was not a significant factor in apparent sensitivity to lysozyme. Cells from rapidly growing cultures (with or without glucose) appeared to be much more sensitive to lysozyme than slower growing cultures or those grown in other media, such as tryptic soy broth (Difco) containing $0.1 \%$ yeast extract (Difco). Harvest treatments such as washing the cells in $\mathrm{Na}_{2}$ EDTA or repeated washes in distilled water reduced apparent sensitivity of the cells to lysozyme. Freezing the cells further reduced apparent sensitivity to lysozyme. Frozen cells resuspended in L-broth did not recover maximal apparent sensitivity to lysozyme for at least two doublings of the culture turbidity. Apparent sensitivity to lysozyme was maximal when rapidly growing cells from early exponential phase (100-150 Kletts units using a no. 66, red filter) were collected and resuspended in lysozyme without rinsing. These results suggested the involvement of a labile factor associated with the cells during rapid growth, which conferred apparent, rather than actual, sensitivity to lysozyme. Subsequent experiments gave equivalent lysis and release of plasmid DNA with or without lysozyme addition, indicating that intrinsic autolytic factors, rather than lysozyme, were primarily responsible for removal of the cell wall.

Autolytic formation of $B$. thuringiensis protoplasts (autoplasts) was observed by phasecontrast microscopy. Autoplasts were formed by extrusion through a small hole in the encasing cell wall. Rate and efficiency of autoplast formation was dependent upon the same factors as identified for apparent sensitivity of the cells to lysozyme. Autoplast formation was optimal at $37^{\circ} \mathrm{C}$ in $50 \mathrm{~mm}$-Tris $/ \mathrm{HCl}, \mathrm{pH} 7.5$, containing $10 \mathrm{~mm}-\mathrm{MgCl}_{2}, 1 \mathrm{mM}-\mathrm{CaCl}_{2}, 1 \mathrm{~mm}-\mathrm{MnCl}_{2}$, $0 \cdot 1 \mathrm{mM}-\mathrm{CoCl}_{2}, 1 \mathrm{mM}$-dithiothreitol, bovine serum albumin $\left(1 \mathrm{mg} \mathrm{ml}^{-1}\right)$, and $350-500 \mathrm{~mm}-$ 
sucrose. Both the rate and efficiency of autoplast formation could be increased by addition of an exogenous preparation of $B$. thuringiensis autolytic enzymes; however, protoplasts prepared in this way exhibited altered refractive index, changing from phase-dark to phase-transparent during subsequent incubation. Use of exogenous autolytic enzymes for preparation of $B$. thuringiensis protoplasts would require additional purification of the autolytic enzymes to remove membrane damaging factors. Autoplasts prepared without addition of exogenous enzyme were stable in phase character for several days.

$B$. thuringiensis cell walls were purified to remove endogenous lytic factors so that hydrolytic activity of various enzymes could be compared. Initial assays attempted to measure hydrolytic activity turbidimetrically (no. 42, blue filter) using cell wall suspensions, but addition of lysozyme $\left(1-10 \mathrm{mg} \mathrm{ml}^{-1}\right)$ or potassium phosphate $(0.1 \mathrm{M})$ resulted in aggregation and precipitation of the cell walls. For this reason, purified cell walls dyed with Procion red MX5B were used. Release of dye corresponded to decreased size of the cell wall pellet following centrifugation. This method was used for comparative studies but was not standardized for quantification of absolute enzyme activity. Only the $N$-acetylmuramidase from $S$. globisporus (mutanolysin) and the autolytic enzyme preparation from $B$. thuringiensis were effective in hydrolysing the purified cell walls in either the presence or absence of the dye, while lysozyme, lysostaphin, chitinase, trypsin and $B$. subtilis proteinase were completely ineffective. In addition, lysozyme inhibited release of dye by both the $S$. globisporus enzyme and the autolytic enzyme preparation.

Optimal conditions for hydrolytic release of dye by mutanolysin appeared to be at $37^{\circ} \mathrm{C}$ with pH 7.9-8.6. Dibasic cations were inhibitory to mutanolysin activity in the order $\mathrm{Mn}^{2+}$ and $\mathrm{Co}^{2+}$ (most inhibitory) followed by $\mathrm{Ca}^{2+}$ then $\mathrm{Mg}^{2+}$. Since at least $10 \mathrm{mM}-\mathrm{MgCl}_{2}$ was required to stabilize $B$. thuringiensis autoplasts, various buffers were tested to determine if $\mathrm{Mg}^{2+}$ exhibits different levels of inhibition in different buffers. In general, $10 \mathrm{mM}-\mathrm{MgCl}_{2}$ resulted in $50 \%$ inhibition of mutanolysin activity in different buffer systems, including several different salts of Tris. The exceptions to this general observation occurred with buffers containing phosphate or citrate $(0-30 \%$ inhibition $)$, which can sequester $\mathrm{Mg}^{2+}$ either by formation of a poorly soluble salt or by chelation.

Lysozyme-resistant species of cariogenic Streptococcus have been shown to be sensitive to mutanolysin (Calandra \& Cole, 1980; Siegel et al., 1981). Other Gram-positive bacteria also show different sensitivities to lysozyme or mutanolysin (Yokogawa et al., 1975; Zipperle et al., 1984). The basis for the different actions of lysozyme and mutanolysin on whole cells or purified cell walls may relate to the presence of accessory structures such as teichoic or teichuronic acids, or protein components of the cell surface and cell wall, rather than to any intrinsic differences in the peptidoglycan structure (Knox et al., 1979; Nesbitt et al., 1980). Other species exhibit $O$ acetylation of glycan chains (Brumfitt et al., 1958) and incomplete $N$-acetylation of amino sugars (Araki et al., 1972) as the basis for lysozyme resistance.

Since resistance to lysozyme hydrolysis may result from modification of the peptidoglycan or from the presence of accessory cell wall components which limit accessibility of the peptidoglycan, B. thuringiensis cells were converted to spheroplasts by growth in L-broth containing $2 \mathrm{mM}$-D-cycloserine and $0 \cdot 1-0 \cdot 25 \mathrm{M}$-sucrose. Resuspension of the spheroplasts in fresh medium without cycloserine resulted in rapid conversion to bacillary form and recovery of resistance to lysis induced by osmotic shock. Addition of lysozyme to the spheroplasts prevented both the subsequent return to bacillary form and recovery of resistance to osmotic shock.

Lysozyme and mutanolysin lacked nuclease activity; however, lysozyme formed complexes with the plasmid DNA and prevented electrophoretic migration into the gel, necessitating its removal by phenol extraction prior to electrophoretic analysis. Mutanolysin did not interfere with normal electrophoretic migration of the DNA.

Lysozyme was thus not only ineffective in hydrolysing cell walls of $B$. thuringiensis, but may be detrimental to a variety of subsequent biological or biochemical manipulations. Three alternatives to the use of lysozyme are presented. (1) Intrinsic autolytic activity may be utilized to produce cell lysates or protoplasts, but this action was relatively slow. (2) Addition of autolytic enzymes of $B$. thuringiensis (free of proteases and lipases) appeared to be possible and effective. 
(3) Mutanolysin was effective in hydrolysing cell walls of $B$. thuringiensis. Use of mutanolysin at $1 \mathrm{mg} \mathrm{ml}^{-1}$ in $10-50 \mathrm{mM}$-Tris/ $\mathrm{HCl}, \mathrm{pH} 8.0$, resulted in rapid lysis of $B$. thuringiensis cells, or conversion to protoplasts in 10-50 mM-potassium phosphate, $\mathrm{pH} 8 \cdot 0$, with $10-20 \mathrm{mM}-\mathrm{MgCl}_{2}$ and $0 \cdot 3 \mathrm{M}$-sucrose. Additional stability was obtained by addition of $\mathrm{MnCl}_{2}$ and $\mathrm{CaCl}_{2}$ (each to $1 \mathrm{mM}$ ) and bovine serum albumin (to $1 \mathrm{mg} \mathrm{m}^{-1}$ ). Although the optimal temperature was $37-45^{\circ} \mathrm{C}$, similar results were achieved using $10 \mathrm{mg}$ mutanolysin $\mathrm{ml}^{-1}$ at $5{ }^{\circ} \mathrm{C}$.

Mention of a commercial product does not constitute recommendation for use by the Agricultural Research Service, US Department of Agriculture.

\section{REFERENCES}

Alikhanian, S. I., RYabChenko, N. F., Bukanov, N. O. \& SaKanyan, V. A. (1981). Transformation of Bacillus thuringiensis subsp. galleria protoplasts by plasmid pBC16. Journal of Bacteriology 146, 7-9.

araki, Y., Nakatani, T., Nakayama, K. \& Ito, E. (1972). Occurrence of $N$-nonsubstituted glucosamine residues in peptidoglycan of lysozyme-resistant cell walls from Bacillus cereus. Journal of Biological Chemistry 247, 6312-6322.

Azizbekyan, R. R., Belykh, R. A. \& Stepanova, T. V. (1982). Plasmid transformation of protoplasts of Bacillus thuringiensis. Doklady Akadademii Nauk SSSR 262, 226-228 (in Russian).

BRUMfitT, W., WardlaW, A. C. \& PARK, J. T. (1958). Development of lyszyme-resistance in Micrococcus lysodeikticus and its association with an increased $O$ acetyl content of the cell wall. Nature, London 181, 1783-1784.

Calandra, G. B. \& Cole, R. M. (1980). Lysis and protoplast formation of group B streptococci by mutanolysin. Infection and Immunity 28, 1033-1037.

DI JESO, F. (1968). Ammonium sulfate concentration conversion nomograph for $0^{\circ}$. Journal of Biological Chemistry 243, 2022-2023.

ForsberG, C. \& Rogers, H. J. (1971). Autolytic enzymes in growth of bacteria. Nature, London 229, 272-273.

Gonzalez, J. M., JR \& Carlton, B. C. (1982). Plasmid transfer in Bacillus thuringiensis. In Genetic Exchange, a Celebration and a New Generation, pp. 85-95. Edited by U. N. Streips, S. H. Goodgal, W. R. Guild \& G. A. Wilson. New York: Marcel Dekker.

Harkington, C. R. \& Baddiley, J. (1983). Peptidoglycan synthesis by partly autolyzed cells of Bacillus subtilis W23. Journal of Bacteriology 155, 776-792.

Kingan, S. \& Ensign, J. C. (1968a). Chemical composition of the cell wall of Bacillus thuringiensis var. thuringiensis. Journal of Bacteriology 95, 724 726.

KINGAN, S. L. \& ENSIGN, J. C. (1968b). Isolation and characterization of three autolytic enzymes associated with sporulation of Bacillus thuringiensis var. thuringiensis. Journal of Bacteriology 96, 629-638.

KnoX, K. W., Jacques, N. A., Campbell, L. K., WiCken, A. J., Hurst, S. F. \& Bleiweis, A. S. (1979). Phenotypic stability of the cell wall of Streptococcus mutans Ingbritt grown under various conditions. Infection and Immunity 26, 1071-1078.
Lereclus, D., LeCADET, M.-M., Ribier, J. \& DEDONDER, R. (1982). Molecular relationships among plasmids of Bacillus thuringiensis: conserved sequences through 11 crystalliferous strains. Molecular and General Genetics 186, 391-398.

MARTIN, P. A. W. \& DEAN, D. H. (1980a). Genetic manipulation in the insect pathogen Bacillus thuringiensis. In Plasmids and Transposons: Environmental Effects and Maintenance Mechanisms, pp. 151-161. Edited by C. Stuttard \& K. R. Rozee. New York Academic Press.

Martin, P. A. W. \& Dean, D. H. (1980b). Genetics and genetic manipulation of Bacillus thuringiensis. In Microbial Control of Pests and Plant Diseases 1970 1980, pp. 299-311. Edited by H. D. Burges. London : Academic Press.

MARTIN, P. A. W., LoHR, J. R. \& DEAN, D. H. (1981) Transformation of Bacillus thuringiensis protoplasts by plasmid deoxyribonucleic acid. Journal of Bacteriology 145, 980-983.

Miteva, V. I., Shivarova, N. I. \& Grigorova, R. T (1981). Transformation of Bacillus thuringiensis protoplasts by plasmid DNA. FEMS Microbiology Letters 12, 253-256.

Nesbitt, W. E., StaAt, R. H., Rosan, B., Taylor, K. G. \& DoYLE, R. J. (1980). Association of protein with the cell wall of Streptococcus mutans. Infection and Immunity 28, 118-126.

Oliver, C. N. \& STadtman, E. R. (1983). A proteolytic artifact associated with the lysis of bacteria by egg white lysozyme. Proceedings of the National Academy Sciences of the United States of America 80, 21562160.

Siegel, J. L., Hurst, S. F., Liberman, E. S., Coleman, S. E. \& BleiweIS, A. S. (1981). Mutanolysin-induced spheroplasts of Streptococcus mutans are true protoplasts. Infection and Immunity 31, 808-815.

TEMEYER, K. B. (1984). Larvicidal activity of Bacillus thuringiensis subsp. israelensis in the dipteran Haematobia irritans. Applied and Environmental Microbiology 47, 952-955.

Yokogawa, K., Kawata, S., Takemura, T. \& Yoshimura, Y. (1975). Purification and properties of lytic enzymes from Streptomyces globisporus 1829 . Agricultural and Biological Chemistry 39, 1533-1543.

ZIPPERLE, G. F., JR, EZZELL, J. W., JR \& DOYLE, R. J. (1984). Glucosamine substitution and muramidase susceptibility in Bacillus anthracis. Canadian Journal of Microbiology 30, 553-559. 